\title{
PELATIHAN BAHASA INGGRIS BERBASIS DARING DENGAN KONSEP MENTORING DAN TUTOR TEMAN SEBAYA
}

\author{
Fandita Tonyka Maharani \\ Departemen Kesehatan Masyarakat, Universitas Pembangunan Nasional Veteran Jakarta \\ fanditatonykamaharani@gmail.com
}

\begin{abstract}
The globalization and disruption era creates effects for the human being; one is the connection between people without boundaries. This thing also brings up the importance of English language usage. This community service was conducted through online English training, which consists of 8 meetings between June-July 2020. The training includes 1 mentor and 3 participants. The initial assessment was conducted to know the participants' abilities and categorize them into Basic, Intermediate, Advanced classes. This training was categorized in the Basic class. Each meeting was divided into three sessions, which enable the mentor and participants to have conversations with each other. This training uses Conversation Method. The participants were excited, which can be seen by the $87.5 \%$ participatory rate. The final assessment shows an improvement for the participants'English capability, and they can continue to Intermediate class.
\end{abstract}

Keywords: Training, English, Mentor, Peer

\begin{abstract}
Abstrak
Globalisasi dan disrupsi membawa banyak dampak bagi manusia, salah satunya adalah terhubungnya semua orang di dunia ini tanpa memperhatikan batasan ruang dan waktu. Hal ini membuat penguasaan bahasa Inggris menjadi penting bagi semua orang. Pengabdian masyarakat berupa pelatihan bahasa Inggris ini dilakukan secara daring selama 8 kali pertemuan selama JuniJuli 2020. Pelatihan ini melibatkan 1 orang mentor dan 3 orang peserta. Assessment awal dilakukan untuk mengetahui kemampuan peserta dan mengelompokkannya berdasarkan kemampuan tersebut (Basic, Intermediate, Advance). Pelatihan ini termasuk kelas Basic. Setiap pertemuan dibagi menjadi 3 sesi yang memungkinkan mentor dan peserta bisa bercakap-cakap satu sama lain. Pelatihan ini menggunakan metode percakapan (Conversation Method). Peserta sangat partisipatif dan antusias yang ditunjukkan dengan tingkat kehadiran semua peserta sebesar $87.5 \%$. Assessment yang dilakukan di akhir pertemuan menunjukkan adanya peningkatan kemampuan bahasa Inggris peserta dan mereka dapat melanjutkan ke kelas Intermediate.
\end{abstract}

Kata Kunci: Pelatihan, Bahasa Inggris, Mentor, Teman Sebaya

\begin{tabular}{l|l|l} 
Submitted: $2020-09-15$ & Revised: $2020-10-06$ & Accepted: $2020-10-09$
\end{tabular}

\section{Pendahuluan}

Memasuki tahun 2020, tidak dipungkiri dunia telah mengalami globalisasi dan disrupsi yang pada akhirnya membuat seluruh dunia menjadi tersambung, tidak lagi terbatas pada dimensi ruang dan waktu. Globalisasi dipandang menjadi sebuah kesempatan yang memiliki berbagai macam keuntungan, seperti terbukanya berbagai kesempatan dalam bidang ekonomi dan pertukaran berbagai macam ide (ILO, 2004). Salah satu aspek penting dalam hal ini adalah kemampuan berbahasa asing, khususnya bahasa Inggris. Bahasa Inggris merupakan salah satu bahasa resmi yang digunakan oleh Persatuan Bangsa-Bangsa (PBB) (United Nations, 2020).

Studi menyatakan bahwa penguasaan bahasa Inggris sangat diperlukan untuk mendukung era globalisasi (Susanti, 2002; Handayani, 2015). Lebih jauh lagi, sebuah 
studi menyatakan bahwa metode pembelajaran bahasa Inggris mempunyai peranan yang besar dalam mendukung keberhasilan penguasaan bahasa Inggris (Yamin, 2017). Terdapat beberapa metode pembelajaran bahasa Inggris yang dapat diterapkan yaitu: 1 . Metode Langsung (Direct Method) 2. Metode Berlitz (Berlitz Method) 3. Metode Alami (Natural Method) 4. Metode Percakapan (Conversation Method) 5. Metode Phonetic (Mendengar dan Mengucapkan) 6. Metode Practice - Theory 7. Metode Membaca (Reading Method) 8. Metode Bicara Lisan 9. Metode Praktek Pola-pola Kalimat (PatternPractice Method) (Yamin, 2017).

Mengingat urgensi penggunaan bahasa Inggris dalam era globalisasi, pelatihan dan pendidikan bahasa Inggris penting untuk dilakukan. Pelatihan bahasa Inggris ini dilakukan secara daring mengingat pelatihan yang dilakukan pada bulan Juni-Juli 2020 ini berada pada masa pandemi Covid-19. Pelatihan bahasa Inggris ini menggunakan Metode Percakapan (Conversation Method) yang melibatkan mentor dan teman sebaya.

\section{Metode}

Metode yang digunakan dalam pelatihan bahasa Inggris ini adalah Metode Percakapan (Conversation Method) yang melibatkan mentor dan teman sebaya. Pelatihan diadakan satu minggu sekali selama kurun waktu Juni-Juli 2020. Sebelum pelatihan, diadakan assessment kemampuan peserta. Peserta dibagi ke dalam kelas tertentu (Basic, Intermediate, Advance) sesuai dengan kemampuan masing-masing. Assessment juga dilakukan di akhir pelatihan. Pelatihan berbasis daring ini termasuk kelas Basic dengan menggunakan aplikasi Video Call selama 1 jam. Terdapat 1 orang mentor dan 3 orang peserta. Setiap pertemuan pelatihan, dibagi menjadi 3 sesi (tabel 1) Mentor memulai kelas dan memberikan topik percakapan (tabel 2). Setelah itu, mentor bercakap-cakap dengan peserta satu persatu. Peserta bercakap-cakap satu sama lain dengan metode yang telah ditentukan. Mentor akan bergabung pada sesi 3 yang melibatkan semua peserta.

Tabel 1. Agenda Pelatihan

\begin{tabular}{|c|c|c|c|}
\hline Sesi 1 & & Sesi 2 & Sesi 3 \\
\hline- & $\begin{array}{lr}\text { Mentor } & \text { membuka } \\
\text { kelas } & \text { dan } \\
\text { menentukan } & \text { topik } \\
\text { percakapan } & \end{array}$ & \multirow[t]{2}{*}{$\begin{array}{l}\text { Peserta dibagi berpasangan } \\
\text { dan bercakap-cakap dengan } \\
\text { topik yang telah ditentukan }\end{array}$} & \multirow{2}{*}{$\begin{array}{l}\text { Diskusi kelompok yang } \\
\text { dipimpin oleh mentor dan } \\
\text { melibatkan semua peserta } \\
\text { tentang topik yang telah } \\
\text { ditentukan }\end{array}$} \\
\hline- & $\begin{array}{lr}\text { Mentor } & \text { bercakap- } \\
\text { cakap } & \text { dengan } \\
\text { peserta satu persatu }\end{array}$ & & \\
\hline
\end{tabular}

Tabel 2. Topik Pelatihan

\begin{tabular}{cl}
\hline Pertemuan & Topik Pelatihan \\
\hline 1 & Self-Introduction \\
2 & Hobbies \\
3 & Favourite Foods \\
4 & Favourite Tourism Attraction \\
5 & Subject Learnt at the Universities \\
6 & Favourite Cities \\
7 & Favourite Countries \\
8 & Ideas of the Future \\
\hline
\end{tabular}




\section{Hasil dan Pembahasan}

Asssessment peserta dilakukan sebelum pelatihan dimulai. Pelatihan bahasa Inggris ini termasuk ke dalam kelas Basic yang bertujuan untuk meningkatkan kemampuan bahasa Inggris peserta dalam kehidupan sehari-hari. Peserta sangat partisipatif dan kooperatif ditandai dengan kehadiran peserta yang masing-masing mencapai $87.5 \%$ (tabel 3).

Tabel 3. Tingkat Kehadiran Peserta selama 8 Pertemuan Pelatihan

\begin{tabular}{ll}
\hline Peserta & Kehadiran (\%) \\
\hline A & 87.5 \\
B & 87.5 \\
C & 87.5 \\
\hline
\end{tabular}

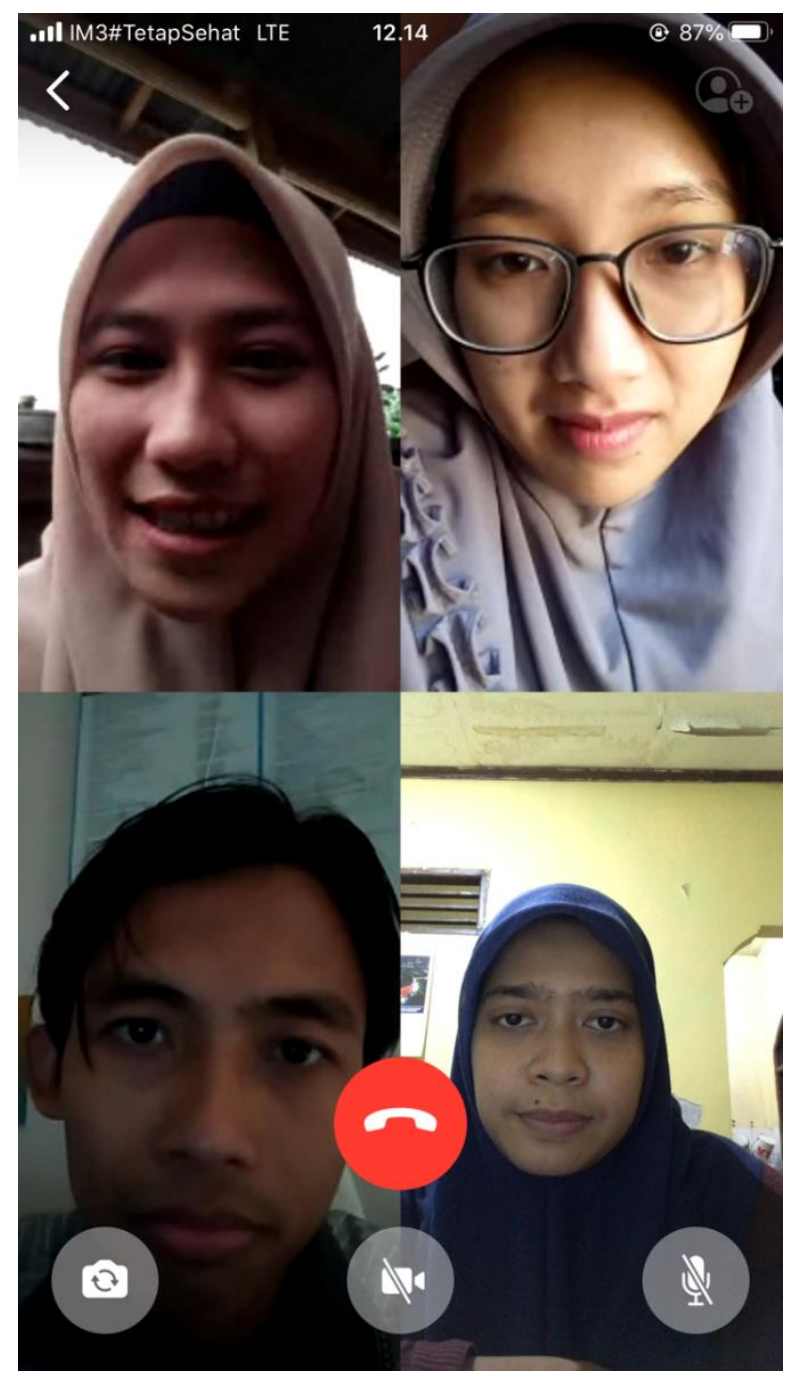

Gambar 1. Pelatihan dilakukan Secara Daring

Assessment dilakukan pada pertemuan akhir. Pada pertemuan terakhir, semua peserta menyatakan puas dan termotivasi lebih lanjut untuk mempelajari bahasa Inggris. 
Assessment akhir juga menyatakan bahwa peserta mengalami peningkatan kemampuan bahasa Inggris dan dapat dilanjutkan ke kelas Intermediate (tabel 4).

Tabel 4. Hasil Assessment Sebelum dan Sesudah Pelatihan

\begin{tabular}{lll}
\hline Peserta & $\begin{array}{l}\text { Assessment Sebelum } \\
\text { Pelatihan }\end{array}$ & $\begin{array}{l}\text { Assessment Sesudah } \\
\text { Pelatihan }\end{array}$ \\
\hline A & Basic & Lanjut ke Intermediate \\
B & Basic & Lanjut ke Intermediate \\
C & Basic & Lanjut ke Intermediate \\
\hline
\end{tabular}

\section{Kesimpulan}

Dalam kegiatan pengabdian masyarakat yang berupa pelatihan bahasa Inggris berbasis daring ini menggunakan Metode Percakapan (Conversation Method) yang melibatkan mentor dan teman sebaya. Tabel 4 menunjukkan bahwa terdapat peningkatan kemampuan bahasa Inggris peserta setelah dilakukan pelatihan selama 8 kali pertemuan. Peserta diharapkan dapat meningkatkan kemampuan bahasa Inggrisnya lebih lanjut melalui kelas Intermediate.

\section{Daftar Pustaka}

Handayani, Sri. (2015). Penguasaan Kosa Kata Dan Kemampuan Membaca Bahasa Inggris. Jurnal Profesi Pendidik

ILO. (2004). A Fair Globalization: Creating Opportunities for All. Switzerland: Geneva Jurnal Pesona Dasar

Susanti, Ratna. (2002). Penguasaan Kosa Kata Dan Kemampuan Membaca Bahasa Inggris. Jurnal Pendidikan Penabur

United Nations. (2020). Official Languages. Available from: https://www.un.org/en/sections/about-un/officiallanguages/index.html\#: :text=There\%20are\%20six\%20official\%20languages, $\%$ 2C\%20French\%2C\%20Russian\%20and\%20Spanish. (Accessed 15 September 2020)

Yamin, Muhammad. (2017). Metode Pembelajaran Bahasa Inggris Di Tingkat Dasar. 